\title{
Multivariate analysis of productive and nutritional traits and feeding behavior of sheep fed roughage-free diets
}

\author{
Elizângela Oliveira Cardoso-Santana1 ${ }^{\text {iD }}$, Hermógenes Almeida de Santana Júnior ${ }^{1 *}$ (iD, \\ Eva Clícia de Jesus Almeida² iD, Tiago Brandão Freitas ${ }^{3}$, Cibelle Borges Figueiredo ${ }^{1}$ iD, \\ Carlos Tadeu dos Santos Dias ${ }^{4}$, Paulo Luiz Souza Carneiro² ${ }^{2}$, Carlos Henrique Mendes Malhado² \\ ${ }^{1}$ Universidade Estadual do Piauí, Campus Deputado Jesualdo Cavalcanti, Corrente, PI, Brasil. \\ ${ }^{2}$ Universidade Estadual do Sudoeste da Bahia, Campus Jequié, Jequié, BA, Brasil. \\ ${ }^{3}$ University of Illinois at Urbana-Champaign, Urbana, IL, USA. \\ ${ }^{4}$ Universidade de São Paulo, Piracicaba, SP, Brasil.
}

\begin{abstract}
The objective of this study was to evaluate productive traits in sheep fed roughage-free diets by multivariate analysis. Forty lambs were used in this study: 20 Santa Inês animals, consisting of 10 uncastrated males and 10 females; and 20 crossbreds ( $1 / 2$ Santa Inês $\times$ Dorper), consisting of 10 uncastrated males and 10 females, at an average age of five months. Lambs were randomly allocated into the following treatments: Santa Inês males fed once daily (SM1); Santa Inês males fed twice daily (SM2); Santa Inês females fed once daily (SF1); Santa Inês females fed twice daily (SF2); crossbred males fed once daily (CM1); crossbred males fed twice daily (CM2); crossbred females fed once daily (CF1); and crossbred females fed twice daily (CF2). In the multivariate analysis, a difference was detected between the mean values for production classes and feeding-behavior variables (Wilks, Pillai, Hotelling-Lawley, and Roy tests). Tocher's optimization method had two groups formed: Group I, comprising treatments SM1, SM2, SF1, SF2, CF1, and CF2; and Group II, containing treatments CM1 and CM2 (crossbred males). When production and cud chews per day were evaluated, neutral detergent fiber digestibility and final weight were the performance-digestibility variables that most contributed to explaining the variation between treatments. When the feeding behavior was assessed, the time spent on other activities was the variable that most contributed. The crossbred genotype $(1 / 2$ Santa Inês $\times$ Dorper) and the male sex have superior performance for weight-related traits. However, when these animals are confined with females, it is recommended to supply the feed only once daily, irrespective of the genetic group.
\end{abstract}

Key Words: feedlot, genotype, lamb

\section{Introduction}

The feeding of ruminants in Brazil is based mainly on forages, which makes these animals vulnerable at certain times of the year due to the low quality and/or availability of pastures, leading to low productivity rates. In the Northeast region, these low yields are even more evident due to the poor distribution of rainfall. This fact has been crucial to the development of meat sheep farming in northeastern Brazil, where it is undertaken as an activity secondary to beef cattle farming. However, new prospects have drawn the attention to the profitability of this activity by virtue of its shorter production cycle, which allows the return of invested capital in less time.

Received: October 15, 2017

Accepted: May 1, 2018

*Corresponding author: hsantanajunior@hotmail.com

Copyright @ 2018 Sociedade Brasileira de Zootecnia. This is an Open Access article distributed under the terms of the Creative Commons Attribution License (http://creativecommons.org/licenses/by/4.0/), which permits unrestricted use, distribution, and reproduction in any medium, provided the original work is properly cited.
To meet the nutritional and market demands, alternatives have been created to ensure the reduction of seasonal effects of forage production and the generation of products at more affordable prices for the population. The use of the so-called high-grain diets has often been mentioned as a solution to the productivity problem in sheep rearing, providing a number of benefits. According to Ribeiro et al. (2011), these benefits are the lower animal mortality brought about by the greater control of health and the better control of the diets.

In ruminants, the effective fiber is an element of paramount importance to the ruminal health. The use of diets without a roughage component during the finishing stage of ruminants has been an important object of research, mainly regarding the impact of this type of system on production variables. Some important aspects in the use of a roughage-free diet for sheep should be elucidated, such as its effects on intake, digestibility, and performance. However, restricting the use of fiber may lead to metabolic disorders in sheep, which can have a lower impact when animals are well adapted to the diet. 
The evaluation of production, intake, digestibility, and weight generates a large number of variables that can compromise understanding; furthermore, many of these variables are highly correlated.

A set of data with a restricted number of replicates, without comparisons in terms of number of variables, using univariate analysis, may compromise data interpretation. Multivariate statistics is defined as a set of statistical methods used in situations in which several variables are measured simultaneously in each experimental unit. The use of multivariate techniques allows for the combination of multiple pieces of information contained in the experimental unit (Cruz and Regazzi, 1994).

Principal component analysis is a multivariate technique for modeling the covariance structure. The technique was initially described by Pearson (1901), and practical computational methods were much later mentioned by Hotelling (1933, 1936), who employed them with the specific purpose of analyzing correlation structures. Principal component analysis is a multivariate statistical technique that linearly transforms an original set of variables initially correlated with each other into a substantially smaller set of uncorrelated variables that contains the largest part of the information from the original set. The objective of this study was to evaluate productive and nutritional traits of sheep fed roughage-free diets using multivariate analysis.

\section{Material and Methods}

This study was carried out in strict accordance with the recommendations in the Guide for the National Council for Animal Experiments Control (CONCEA). Experimental procedures were approved by the local Committee of Ethics on Animal Experimentation (approval no. 10921/15). The experiment was carried out in the municipalities of Jequié (13 $51^{\prime} 27^{\prime \prime} \mathrm{S}$ latitude and $40^{\circ} 05^{\prime} 01^{\prime \prime} \mathrm{W}$ longitude) and Itapetinga $\left(15^{\circ} 14^{\prime} 56^{\prime \prime} \mathrm{S}\right.$ latitude longitude $\left.40^{\circ} 14^{\prime} 52^{\prime \prime} \mathrm{W}\right)$ in Bahia, Brazil.

Forty animals were used in the experiment: 20 Santa Inês, consisting of 10 males with an initial body weight of $30.65 \pm 0.85 \mathrm{~kg}$ and 10 females weighing $32.75 \pm 1.45 \mathrm{~kg}$; and 20 crossbreds $(1 / 2$ Santa Inês $\times$ Dorper), consisting of 10 males with an average weight of $45.20 \pm 0.75 \mathrm{~kg}$ and 10 females with an initial weight of $31.35 \pm 1.45 \mathrm{~kg}$, at an average age of five months. Before the adaptation period, animals were dewormed and had their health assessed to be included in the study.

Animals were housed in collective $30-\mathrm{m}^{2}$ stalls in an open place with natural shading, equipped with a linear feeder at $0.25 \mathrm{~m}$ animal $^{-1}$ and a bucket drinker. The experimental period was 56 days, the first 21 of which were used as a period of acclimation to the handling procedures and the diet, and the other 35 for data collection, between February and March 2013. Adaptation to the diet was a gradual process achieved by substituting $10 \%$ of roughage for the concentrate diet every two days, until it was completely replaced.

Animals were weighed and randomly allocated into the following treatments (groups): Santa Inês males fed once daily (SM1), Santa Inês males fed twice daily (SM2), Santa Inês females fed once daily (SF1), Santa Inês females fed twice daily (SF2), crossbred males fed once daily (CM1), crossbred males fed twice daily (CM2), crossbred females fed once daily (CF1), and crossbred females fed twice daily (CF2).

The diet was formulated to provide a weight gain of $350 \mathrm{~g} \mathrm{day}^{-1}$ (NRC, 2007), composed of coarsely ground com, cottonseed cake, and a buffered mineral-vitamin premix (Table 1).

Feed was supplied ad libitum, adjusted for $5 \%$ to be left as orts to ensure the maximum voluntary intake. The feed was supplied at 08:00 $\mathrm{h}$ for the animals that would be fed once, and also at 15:30 $\mathrm{h}$ for those in the treatments that would be fed twice.

For the chemical analysis, samples of feed and feces were dried in an oven at $55^{\circ} \mathrm{C}$ for $72 \mathrm{~h}$, ground through a knife mill (Tecnal, Piracicaba city, São Paulo State, Brazil) to $1-\mathrm{mm}$ particles, and stored in plastic containers that were then sealed. In the laboratory, samples were analyzed for the levels of dry matter (DM; method 967.03; AOAC, 1990), ash (method 942.05; AOAC, 1990), ether extract (EE; method 920.29; AOAC, 1990), and crude protein (CP; method 981.10; AOAC, 1990).

The fiber content was analyzed by the sequential method described by Van Soest et al. (1991), using the Ankom 200 fiber analyzer (Ankon Technology

Table 1 - Proportion of ingredients and composition of the diet without roughage offered to the sheep

\begin{tabular}{|c|c|}
\hline Proportion of ingredients $\left(\mathrm{g} \mathrm{kg}^{-1}\right)$ & \\
\hline Coarsely ground corn & 557.62 \\
\hline Cottonseed cake & 371.75 \\
\hline Buffered mineral-vitamin premix & 70.63 \\
\hline \multicolumn{2}{|l|}{ Diet composition $\left(\mathrm{g} \mathrm{kg}^{-1}\right)$} \\
\hline Dry matter & 914.04 \\
\hline Crude protein ${ }^{1}$ & 152.53 \\
\hline Ether extract ${ }^{1}$ & 129.06 \\
\hline Non-fiber carbohydrates ${ }^{1}$ & 414.81 \\
\hline Neutral detergent fiber corrected for ash and protein ${ }^{1}$ & 211.87 \\
\hline Total digestible nutrients ${ }^{1}$ & 794.18 \\
\hline
\end{tabular}


Corporation, Macedon, New York, US), and corrected for ash and protein (NDFap) according to Hall (2003).

Non-fiber carbohydrates (NFC) were obtained by the following equation described by Sniffen et al. (1992):

$$
\mathrm{NFC}=100-(\% \mathrm{CP}+\% \mathrm{EE}+\% \mathrm{Ash}+\% \mathrm{NDFap})
$$

Total digestible nutrients (TDN) were calculated as the sum of the digestible fractions of CP, NDFap, NFC, and EE, with EE multiplied by 2.25 .

Dry matter intake was obtained by the following equation:

$$
\mathrm{DMI}=\{(\mathrm{FP} * \mathrm{CMF})-\mathrm{MD}\},
$$

in which DMI is the dry matter intake $\left(\mathrm{kg} \mathrm{day}^{-1}\right)$; FP is the fecal production $\left(\mathrm{kg} \mathrm{day}^{-1}\right)$, using the $\mathrm{LIPE}^{\circledR}$ (isolated and purified lignin from eucalyptus) external marker; CMF is the concentration of the marker in the feces $\left(\mathrm{kg} \mathrm{kg}^{-1}\right)$; and $\mathrm{MD}$ is the marker present in the diet $\left(\mathrm{kg} \mathrm{day}^{-1}\right)$, using the indigestible neutral detergent fiber (iNDF) internal marker, according to Casali et al. (2008).

The apparent digestibility coefficient of the nutrients $\left(\mathrm{N}_{\mathrm{DC}}\right)$ was calculated according to Silva and Leão (1979), as follows:

$\mathrm{N}_{\mathrm{DC}}=$ (nutrient consumed - nutrient excreted/nutrient consumed) $\times 100$.

Animals were weighed at the beginning and end of the experimental period to determine their final weight (FW), average daily gain in the period (ADG), weight gain (WG), and feed conversion (FC). Feed conversion was calculated as the ratio between intake and weight gain in the period.

Variables showing effects of interaction and/or sex, genotype, and frequency of feed supply and the correlation between the variables were used as a selection criterion in the preliminary multivariate analyses.

The variables related to intake were total DMI, DMI per weight, DMI per metabolic weight, organic matter (OM) intake, CP intake, EE intake, NDF intake, total carbohydrate intake, and NFC intake. Variables related to digestibility were digestibility coefficients of DM, $\mathrm{OM}, \mathrm{CP}, \mathrm{EE}$, and NDF and TDN. Performance variables were total weight gain, final weight, total weight gain in the period, ADG, FC, and feed efficiency. The analysis of relative contribution to the total variation, by Singh's method (Singh, 1981), resulted in the discard of the variables whose contribution was lower than $1 \%$. Lastly, the remaining evaluated variables were DMI in $\mathrm{kg} \mathrm{day}^{-1}$, DMI kg BW ${ }^{0.75}$ day $^{-1}$, neutral detergent fiber digestibility $\left(\mathrm{NDF}_{\mathrm{DC}}\right)$, and weight gain (WG).

After the dissimilarity matrices were obtained by the mean Euclidean distance, the association of matrices was analyzed using the Mantel test with 100 permutations and a significance level of $5 \%$.
The new dataset was then subjected to a multivariate analysis (MANOVA), according to the matrix model below:

$$
\mathrm{y}=\mathrm{X} \beta+\varepsilon,
$$

in which $\mathrm{y}=$ vector of observations for each variable; $\beta=$ vector of fixed effects for treatment; $X=$ matrix of incidence of fixed effects; and $\varepsilon=$ vector of random errors associated with each observation.

Principal component analysis was performed, and biplot graphs were generated, and thus the treatmentvariable relationship was interpreted based on the dispersion of the points that represent the treatments over the vectors that represent the variables.

The cluster analyses employed in the study were Tocher's optimization method, adopting the criterion that the average intra-group distance should be smaller than the average inter-group distance, i.e., more similar treatments are allocated in the same group (Cruz et al. 2008); and the UPGMA (unweighted pair group method with arithmetic mean) hierarchical method, to generate the dendrogram with the groups of greater similarity.

Principal component and MANOVA analyses were undertaken using SAS statistical software (Statistical Analysis System, version 9.0). Cluster analyses were performed using Genes software (Cruz, 2009), and graphs were generated using the Past 2.03 computer program (Hammer et al., 2001).

\section{Results}

In the multivariate analysis, a difference was detected $(\mathrm{P}<0.001)$ between the vectors of means for the production variables (DMI in $\mathrm{kg} \mathrm{day}^{-1}$, DMI in $\mathrm{kg} \mathrm{BW}^{0.75}$ day $^{-1}$, $\mathrm{NDF}_{\mathrm{DC}}, \mathrm{FW}, \mathrm{WG}$, and FC), by the adopted tests (Wilks Pillai, Hotelling-Lawley, and Roy).

The choice of the number of components was made based on the percentage of response of accumulated variation being greater than $80 \%$. Thus, two principal components were considered. Among the variables considered variable (DMI in $\mathrm{kg} \mathrm{day}^{-1}$, DMI in $\mathrm{kg}$ $\mathrm{BW}^{0.75}$ day $^{-1}, \mathrm{NDF}_{\mathrm{DC}}, \mathrm{FW}, \mathrm{WG}$, and $\mathrm{FC}$ ), the first component explained $55.62 \%$ and the second, $30.61 \%$ of the total variation, with an accumulated variation of $86.23 \%$.

The two principal components were given by: $\mathrm{PC}_{\text {prod }}:\left(0.393630 * \mathrm{DMI}\right.$ in kg day $\left.{ }^{-1}\right)+\left(0.256278 * \mathrm{NDF}_{\mathrm{DC}}\right)$ $+(0.509696 * \mathrm{FW})+(0.401127 * \mathrm{WG})-(0.471585 * \mathrm{FC})-$ $\left(0.369178 * \mathrm{DMI}\right.$ in $\left.\mathrm{kg} \mathrm{BW}^{0.75} \mathrm{day}^{-1}\right)$

PC2 $2_{\text {prod }}:\left(0.420983 * \mathrm{DMI}\right.$ in kg day $\left.{ }^{-1}\right)+\left(0.621407 * \mathrm{NDF}_{\mathrm{DC}}\right)$ $+(0.005203 * \mathrm{FW})-(0.404508 * \mathrm{WG}$ in $\mathrm{kg})-$

$(0.056011 * \mathrm{FC})+\left(0.519456^{*} \mathrm{DMI}\right.$ in $\left.\mathrm{kg} \mathrm{BW}^{0.75} \mathrm{day}^{-1}\right)$ 
In $\mathrm{PC} 1_{\text {prod }}$, variables $\mathrm{FW}, \mathrm{WG}$, and $\mathrm{FC}$ stood out. This set showed higher eigenvectors, corresponding to the variables with the greatest variability and, thus, greatest dissimilarities across the treatments, herein termed "weight". Weight variables (final weight, weight gain, and feed conversion) accounted for 55.62\%. The treatments that showed the highest vectors referring to the weight variables in $\mathrm{PC}_{\text {prod }}$ were Santa Inês males fed twice daily and crossbred males fed twice daily, which suggests that the animals of the Santa Inês had lower final weight and weight gain throughout the experiment. In the analysis of $\mathrm{PC} 1_{\text {prod }}$, the most efficient treatments are indicated as those which led to the highest final weight and lowest feed conversion, herein represented by crossbred males fed once daily and crossbred males fed twice daily. This result expresses sexual dimorphism, representing heavier males, which was potentiated by heterosis when the animals were crossed with the Dorper, a breed that provides better weight results than the Santa Inês.

In principal component $2\left(\mathrm{PC} 2_{\text {prod }}\right)$, herein termed "intake" component, the variables with the highest scores were $\mathrm{NDF}_{\mathrm{DC}}$, DMI $\left(\mathrm{kg} \mathrm{BW}^{0.75}\right.$ day $\left.^{-1}\right)$, and DMI $\left(\mathrm{kg} \mathrm{day}^{-1}\right)$ with $0.621407,0.519456$, and 0.420983 , respectively, corresponding to a variability of $30.61 \%$. In this component, the diet-fractionation effect is evident, with all sexes and genetic groups (except Santa Inês males fed once daily) without diet fractionation having the highest means for DMI and $\mathrm{NDF}_{\mathrm{DC}}$. Despite this result, no great effects were observed on the weight-related variables, which may simply be a form of adaptation to the management provided. This principal component evidenced the combination between the factors sex and frequency of supply. This effect is possibly due to the size of the animals, as males are naturally bigger than females and so is their digestive tract. Animals selectively retain larger feed particles and, in this regard, the mash diet combined with a larger reticulorumen increased the rate of passage, reducing $\mathrm{NDF}_{\mathrm{DC}}$. This finding was more visible in the Santa Inês animals, which had a greater impact on their weight gain (Table 2). This effect was not noted in the other treatments due to the lower expression on digestibility, which was offset by the interaction of other nutrients present in the diet.

The biplot analysis (Figure 1) gathers, in a single graph, pieces of information about the difference between the treatments and among the variables. The dissimilarity between treatments is given by the graphic distance between them; the variance is interpreted by the length of the vectors, which represent the variables; and their correlations are represented by the angles formed between two vectors (Franco et al., 2012).

The principal component $\mathrm{PC}_{\text {prod } 1}$ corresponded to the variables directly linked to intake: DMI (in $\mathrm{kg} \mathrm{day}^{-1}$ and $\mathrm{kg} \mathrm{BW}{ }^{0.75}$ day $^{-1}$ ) and $\mathrm{NDF}_{\mathrm{DC}}$. The treatments that most related to these vectors were crossbred females fed once daily, Santa Inês females fed once daily, and crossbred males fed once daily, of the animals that received the diet in a single portion daily (Figure 1).

Variables FW, WG, and $\mathrm{FC}$ are related to the $\mathrm{PC}_{\text {prod2 }}$ axis on the biplot graph (Figure 1). Greater angularity was observed between the vectors, demonstrating a lower correlation. The lower correlation between these variables can be explained by the difference in expression of the units of absolute weight or in weight gain in a given period and conversion of feed into weight.

Studies of dissimilarity meet certain goals in which they provide information about the degree of similarity or difference between two or more groups of individuals. However, the number of dissimilarity estimates obtained is relatively high when there is a large number of groups, which often makes it impossible to recognize homogeneous groups by a simple visual assessment. This created scattered points in the biplot graph, making it impossible to establish groups with similar averages. Tocher's method was performed to observe the behavior of groups among the tested treatments. The results of

Table 2 - Mean values for nutritional, productive, and feed-behavior traits in sheep fed diets without roughage

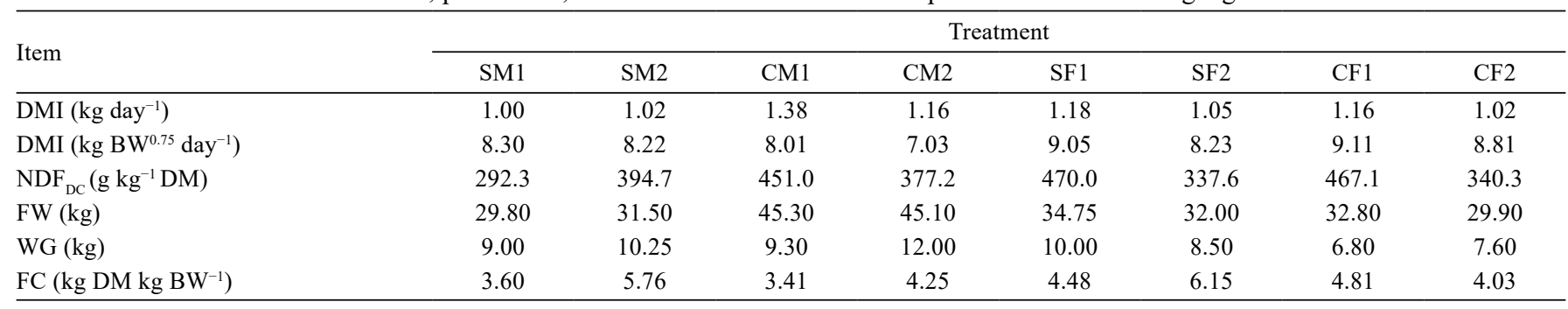

SM1 - Santa Inês males fed once daily; SM2 - Santa Inês males fed twice daily; SF1 - Santa Inês females fed once daily; SF2 - Santa Inês females fed twice daily; CM1 - crossbred males fed once daily; CM2 - crossbred males fed twice daily; CF1 - crossbred females fed once daily; CF2 - crossbred females fed twice daily.

$\mathrm{DMI}$ - dry matter intake; $\mathrm{BW}^{0.75}$ - metabolic weight; $\mathrm{NDF}_{\mathrm{DC}}$ - digestibility coefficient of neutral detergent fiber; DM - dry matter; FW - final weight, WG - weight gain, FC - feed conversion; BW - body weight. 
Tocher's optimization method led to the formation of two groups for the production traits (Table 3). This analysis allowed us to identify the most similar treatments by the formation of groups, based on the dissimilarity matrix, using all variables.

As demonstrated in the principal component analysis, Tocher's method also separates groups based on the variables that present higher variability. In the present study, weight contributed to a greater dissimilarity across the treatments, separating the male crossbred animals from the other treatments. This result also corroborates the graph in Figure 1, in which treatments crossbred males fed once daily and crossbred males fed twice daily showed a shorter distance from the vectors of FW and WG than the other treatments, which was a consequence of the common difference in weight in male animals that was potentiated by the heterosis effect, in the crossbreds.
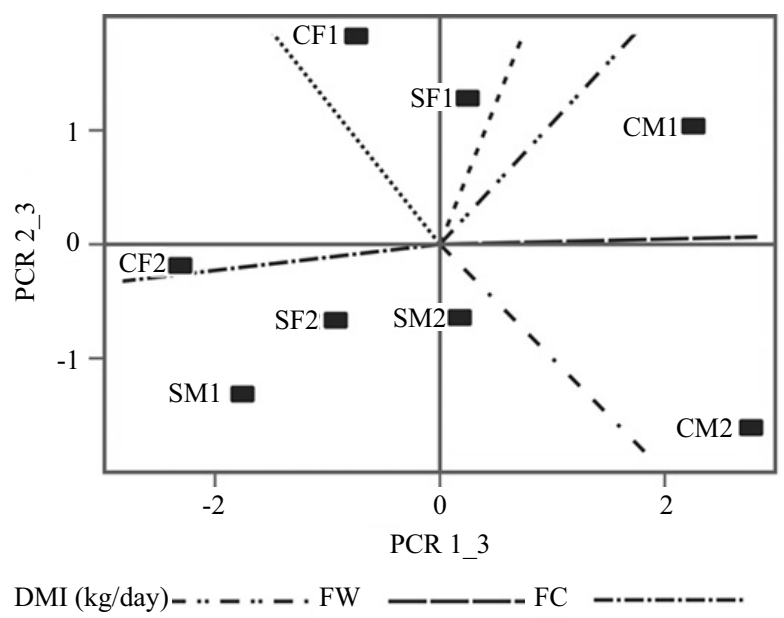

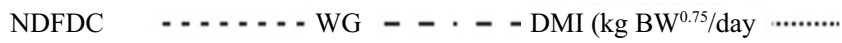

SM1- Santa Inês males fed once daily; SM2 - Santa Inês males fed twice daily; SF1 - Santa Inês females fed once daily; SF2 - Santa Inês females fed twice daily; CM1 - crossbred males fed once daily; CM2 - crossbred males fed twice daily; CF1 - crossbred females fed once daily; CF2 - crossbred females fed twice daily.

${ }^{1}$ DMI - dry matter intake (kg/day); NDFDC - digestibility coefficient of neutral detergent fiber; FW - final weight; WG - weight gain; FC - feed conversion; DMI (kg BW $0.75 /$ day)

Figure 1 - Biplot graph of productive traits ${ }^{1}$ of sheep fed diets without roughage.

Table 3 - Clustering of treatments by Tocher's optimization method, based on the mean Euclidean distance, for production variables of sheep fed diets without roughage

\begin{tabular}{lc}
\hline Group & Treatment \\
\hline I & SM1, SM2, SF1, SF2, CF1, and CF2 \\
II & CM1 and CM2 \\
\hline
\end{tabular}

SM1 - Santa Inês males fed once daily; SM2 - Santa Inês males fed twice daily; SF1 - Santa Inês females fed once daily; SF2 - Santa Inês females fed twice daily; CM1 - crossbred males fed once daily; CM2 - crossbred males fed twice daily; CF1 crossbred females fed once daily; CF2 - crossbred females fed twice daily.
Group I included treatments Santa Inês males fed once daily, Santa Inês males fed twice daily, Santa Inês females fed once daily, Santa Inês females fed twice daily, crossbred females fed once daily, and crossbred females fed twice daily. This group is composed of animals of different genotypes (Santa Inês and crossbreds), different sexes (males and females), and different feeding frequencies (once and twice daily), comprising all individuals of the Santa Inês genotype and crossbred females. This group had the animals with the highest average DMI in $\mathrm{kg}$ day $^{-1}$ and $\mathrm{kg} \mathrm{BW}^{0.75}$ day $^{-1}$, the lowest $\mathrm{FW}$ values, and consequently the highest $\mathrm{FC}$ values.

Treatments with the Santa Inês breed did not express any variable showing the potential of this group when receiving the roughage-free diet, even considering different sexes and frequencies of feed supply. These animals are known for traits that are important in a production system such as good adaptability to arid regions with restricted food availability. However, in roughage-free feedlot systems, animals of that genotype did not display good performance. In this case, the maternal line can be used for lamb production in view of its higher rusticity and prolificacy and lack of reproduction seasonality in comparison with meat breeds (Malhado et al., 2008). The crossbred females were included in group I due to their lower conformation, which led to a lower weight, besides higher $\mathrm{FC}$ values.

Group II comprised treatments crossbred males fed once daily and crossbred males fed twice daily, consisting of crossbred and male animals. These showed the highest FW and DMI in $\mathrm{kg}^{-1 a y^{-1}}$, the lowest DMI in $\mathrm{kg}$ $\mathrm{BW}^{0.75} \mathrm{day}^{-1}$, and consequently the lowest $\mathrm{FC}$ ratios. These results were associated with the effects of sex promoted by steroid hormones in males, mainly testosterone, and the genetic gain provided by the cross with the Dorper breed.

\section{Discussion}

The variables that most contributed to the formation of the two treatment groups were weight $\left(\mathrm{PC}_{\text {prod }}\right)$ and intake $\left(\mathrm{PC} 2_{\text {prod }}\right)$.

The evaluated factors enabled the combination of parameters such as sexual dimorphism and hormonal influence (Pacheco and Quirino, 2008) and the effect of heterosis, ensuring a higher weight and an intermediate feed conversion ratio across the treatments for crossbred animals. Purchas (1991) stressed that uncastrated animals typically have a higher growth rate, and the composition of their gain is characterized by a greater protein content over fat, resulting in higher feed efficiency when compared with 
castrated males or females, within the same contemporary group.

For $\mathrm{PC} 2_{\text {prod }}$, which requires another explanation for the differentiation between the treatments, positive and high scores were observed for variables DMI (in kg day ${ }^{-1}$ and $\mathrm{kg} \mathrm{BW}^{0.75}$ day $^{-1}$ ) and $\mathrm{NDF}_{\mathrm{DC}}$.

The diet with high nutritional value, which in this study corresponds to the treatment without a roughage source, evidenced even further the weight gain potential of crossbred animals.

Santa Inês animals are adapted to the Brazilian semiarid conditions, where the basis of feeding is forage, which has high amounts of poor-quality fiber. These animals evolutionarily have a particularly longer digestive system to ensure the digestion of this material so that their nutritional requirements can be met. Dorper animals are reared in extensive systems where they consume an array of forage plants, although they are reared under the climatic conditions of South Africa, which are very similar to those of Brazil. Therefore, these animals are able to digest and respond with improved performance when fed high-quality diets. As small ruminants are normally fed ad libitum, voluntary feed intake is crucial in feeding strategies aimed at optimal animal production. Such information can be employed to develop a keener nutritional knowledge for improving small ruminant productivity in the region and afar, where similar conditions prevail (Ocak et al., 2016).

Treatments without diet fractionation led to higher fiber intakes and digestibility. The fact that the feed was available to the animal at all times likely allowed it to control its meals, improving the digestibility of the fiber. Several studies have examined feeding frequency in ruminant nutrition and its effect on DM intake, nutrient digestibility, animal performance, ruminal parameters, and passage rate. However, none was found evaluating the effect of feeding frequency on the nutrition and performance of sheep receiving a high proportion of concentrate feed or the associative effects between the adopted nutritional management and physical characteristics of the dietary fiber.

In cattle, Grant and Albright (2000) reported that an increase in feeding frequency improves the efficiency of nutrient utilization in the rumen, stimulates feed intake, and improves animal performance. Those authors also found that DMI in animals housed collectively is affected by behavioral factors modulated by the environment, management, health, and social interactions. This effect may not be true in sheep, because in spite of being ruminants, this species has a different feeding habit. According to Maggioni et al. (2009), the composition of feed intake in adult animals and in animals of different sizes demonstrates that intake is proportional to the metabolic body weight $\left(\mathrm{BW}^{0.75}\right)$. This measurement seems to have such universality that many researchers express feed intake as a proportion of metabolic body weight to compare results of animals of different sizes (Van Soest, 1994).

Regarding $\mathrm{NDF}_{\mathrm{DC}}$, the supply of the diet in one daily portion increased the time and retention of feed in the rumen, which extended the duration of bacterial attack on the dietary fiber, providing greater digestibility to that fraction. The high correlation between DMI and $\mathrm{NDF}_{\mathrm{DC}}$ is explained by Saenz (2005), who reported that the faster the digesta flows from the rumen, the less time microorganisms have to ferment it, which consequently reduces its digestibility. Passage rate affects microbial degradation and, consequently, microbial growth. The size of the microbial population will also be reduced due to the faster passage. Because of the shorter residence time, the energy required for the maintenance of rumen microorganisms is decreased and, thus, more microbial biomass can be produced per unit of energy generated by the substrate, increasing feed intake (Boudon and Peyraud, 2001).

For FW, WG, and FC, proximity was observed basically among the treatments that had their diet fractionated: crossbred females fed twice daily, Santa Inês females fed twice daily, Santa Inês males fed twice daily, and crossbred males fed twice daily. This result indicates that the fractionation of the diet provided higher mean values for the weight- and FC-related variables. The relationship between feeding frequency and weight was reported by Rakes et al. (1961), who observed that 2.5-year-old males fed one or eight times a day had similar daily weight gain and gain efficiency (weight gain/feed intake). On the other hand, when the authors evaluated the frequency of feeding (one or eight times per day) in young animals (six months old), they observed that those fed eight times a day gained $65 \%$ more weight.

In group I, these results were likely due to the presence of signs of heat in the period of evaluation. According to Cloete et al. (2000), the Dorper breed is characterized by sexual precocity, entering estrus from 213 days of age, with a live weight of $39 \mathrm{~kg}$. Sexual precocity in the crossbred genotype might have contributed for the females to reach the adult weight and promoted heat, masking the true effects of sex and genotype factors on performance traits.

Dorper lambs gain on average 240 to $280 \mathrm{~g}$ per day under vastly different environmental conditions, with a dressing percentage of approximately 50\% (Cloete et al., 2000). At the age of 110-120 days, lambs can achieve a weight of $36 \mathrm{~kg}$, with adult Dorper rams weighing 100-120 kg, and 
adult ewes weighing 60-80 kg. Dorper sheep are generally less-selective grazers, using shrubs and bushes to a greater extent and consuming a larger number of plant species and less herbage per metabolic body size compared with other breeds (Brand, 2000). In his review, the latter author revealed a lack of information on the grazing behavior and diet selection of Dorper sheep under more intensive grazing conditions. There is also a complete lack of scientific information on other behavioral aspects of this unique breed.

Additionally, crossbred females reached adult weight early, starting the deposition of fat in the carcass and increasing feed conversion, as the conversion to fat tissue is less efficient. It should be noted that excess adipose tissue deposition may cause losses to farmers, since this tissue has a low deposition efficiency (Du and Dodson, 2012), requiring great energy expenditures.

\section{Conclusions}

The crossbred genotype $(1 / 2$ Santa Inês $\times$ Dorper $)$ and the male sex have superior performance for weight-related traits. However, when these animals are confined with females, it is recommended to supply feed only once daily, irrespective of the genetic group.

\section{References}

AOAC - Association of Official Analytical Chemistry. 1990. Official methods of analysis. 15th ed. AOAC International, Washington, DC.

Boudon, A. and Peyraud, J. L. 2001. The release of intracellular constituents from fresh ryegrass (Lolium perenne L.) during ingestive mastication in dairy cows: effect of intracellular constituent, season and stage of maturity. Animal Feed Science and Technology 93:229-245. https://doi.org/10.1016/S0377-8401(01)00267-X

Brand, T. S. 2000. Grazing behaviour and diet selection by Dorper sheep. Small Ruminant Research 36:147-158. https://doi.org/ 10.1016/S0921-4488(99)00158-3

Casali A. O.; Detmann, E.; Valadares Filho, S. C.; Pereira, J. C.; Henriques, L. T.; Freitas, S. G. and Paulino, M. P. 2008. Influência do tempo de incubação e do tamanho de partículas sobre os teores de compostos indigestíveis em alimentos e fezes bovinas obtidos por procedimentos in situ. Revista Brasileira de Zootecnia. 37:335-342. https://doi.org/10.1590/S1516-35982008000200021

Cloete, S. W. P.; Snyman, M. A. and Herselman, M. J. 2000. Productive performance of Dorper sheep. Small Ruminant Research 36:119-135. https://doi.org/10.1016/S0921-4488(99)00156-X

Cruz, C. D. 2009. Programa Genes: diversidade genética. Editora UFV, Viçosa, MG. 382p.

Cruz, C. D. and Regazzi, A. J. 1994. Modelo biométricos aplicados ao melhoramento genético. Editora UFV, Viçosa, MG.

Cruz, C. D.; Ferreira, F. M. and Pessoni, L. A. 2008. Biometria aplicada ao estudo da diversidade genética. UFV, Viçosa, MG.

Du, M. and Dodson, M. V. 2012. Advanced techniques to enhance marbling in meat. p.107-115. In: Control of meat quality. Joo, S. T., ed. Research Signpost, Kerala.
Franco, I. L.; Malhado, C. H. M.; Carneiro, P. L. S.; Martins Filho, R.; Pereira, D. G. and Dias, C. T. S. 2012. Interação genótipo x local $\mathrm{x}$ regime alimentar em bovinos Nelore por meio de componentes principais de três modos. Ciência Rural 42:2252-2258. https://doi.org/ 10.1590/S0103-84782012005000105

Grant, R. J. and Albright, J. L. 2000. Feeding behaviour. p.365-382. In: Farm animal metabolism and nutrition. D'Mello, J. P. F., ed. CABI, Wallingford.

Hall, M. B. 2003. Neutral detergent-soluble carbohydrates: nutritional relevance and analysis. University of Florida, Gainesville. 76p.

Hammer, O; Harper, D. A. T. and Ryan, P. D. 2001. Past. Version 2.17C: Paleontological Statistics software package for education and data analysis. Palaeontologia Eletrônica 4(1), art. 4, 9p.

Hotelling, H. 1933. Analysis of a complex of statistical variables into principal components. Journal of Educational Psychology 24:498-520. https://doi.org/10.1037/h0070888

Hotelling, H. 1936. Relations between two sets of variants. Biometrika 28:321-377.

Maggioni, D.; Marques, J. A.; Rotta, P. P.; Zawadzki, F.; Ito, R. H. and Prado, I. N. 2009. Ingestão de alimentos. Semina: Ciências Agrárias 30:963-974.

Malhado, C. H. M.; Carneiro, P. L. S.; Santos, P. F.; Azevedo, D. M. M. R.; Souza, J. C. and Affonso, P. R. M. 2008. Curva de crescimento em ovinos mestiços Santa Inês x Texel criados no sudoeste do estado da Bahia. Revista Brasileira de Saúde e Produção Animal 9:210-218.

NRC - National Research Council. 2007. Nutrient requirements of small ruminants. The National Academies Press, Washington, DC. 362p.

Ocak, S.; Ogun, S. and Yilmaz, O. 2016. Dorper sheep utilizing feed resources efficiently: a Mediterranean case study. Revista Brasileira de Zootecnia 45:489-498. https://doi.org/10.1590/S1806-92902016000800010

Pacheco, A. and Quirino, C. R. 2010. Comportamento sexual em ovinos. Revista Brasileira de Reprodução Animal 34:87-97.

Pearson, K. 1901. On lines and planes of closest fit to systems of points in space. Philosophical Magazine, Series 6, 2(11):559-572.

Purchas, R. W. 1991. Effect of sex and castration on growth and composition. p.203-254. In: Growth regulation in farm animals. Advances in meat research. v.7. Pearson, A. M. and Dutson, T. R., eds. Elsevier, London.

Rakes, A. H.; Lister, E. E. and Reid, J. T. 1961. Some effects of feeding frequency on the utilization of isocaloric diets by young and adult sheep. Journal of Nutrition 75:86-92. https://doi.org/ $10.1093 / \mathrm{jn} / 75.1 .86$

Ribeiro, E. L. A.; Mizubuti, I. Y.; Silva, L. D. F.; Paiva, F. H. P.; Sousa, C. L. and Castro, F. A. B. 2011. Desempenho, comportamento ingestivo e características de carcaça de cordeiros confinados submetidos a diferentes frequências de alimentação. Revista Brasileira de Zootecnia 40:892-898. https://doi.org/10.1590/S1516-35982011000400025

Saenz, E. A. C. 2005. Modelagem da redução do tamanho de partículas na alimentação de ruminantes. Ciência e Agrotecnologia 29:886893. https://doi.org/10.1590/S1413-70542005000400023

Silva, J. F. C. and Leão, M. I. 1979. Fundamentos de nutrição de ruminantes. Livroceres, Piracicaba, SP. 380p.

Singh, D. 1981. The relative importance of characters affecting genetic divergence. The Indian Journal of Genetics and Plant Breeding 41:237-245.

Sniffen, C. J.; O'Connor, J. D. and Van Soest, P. J. 1992. A net carbohydrate and protein system for evaluating cattle diets II. Carbohydrate and protein availability. Journal of Animal Science 70:3562-3577. https://doi.org/10.2527/1992.70113562x

Van Soest, P. J. 1994. Nutritional ecology of the ruminant. Cornell University Press, Corvalis. 476p.

Van Soest, P. J.; Robertson, J. B. and Lewis, B. A. 1991. Methods for dietary fiber, neutral detergent fiber, and non starch polysaccharides in relation to animal nutrition. Journal of Dairy Science 74:35833597. https://doi.org/10.3168/jds.S0022-0302(91)78551-2 